\title{
Relevansi Kebijakan dalam Peningkatan Mutu Pendidikan Agama Islam
}

\author{
Asnawan \\ Dosen Institut Agama Islam Al Falah As-Sunniyyyah \\ Kencong Jember Jawa Timur \\ Email: asnawan@inaifas.ac.id
}

\begin{abstract}
Policies on improving the quality of PAI education through the use of information and communication technology in education in the form of developing systems, methods and learning materials using ICT. This activity will also develop a school information network system, infrastructure and human resources to support its implementation, both in the interests of education management and the learning process. By using ICT in the education of students in regular schools, residents learn in non-formal education and students who need the development of local excellence-based schools in each district of the city; the expansion of education units based on local excellence by regional governments is carried out in order to carry out the mandate of Law Number 20 of 2003 concerning the National

Education System which will be gradually developed in each province and district/city.
\end{abstract}

Keywords: Policy, Education Quality, Islamic Religious Education (PAI)

\section{Pendahuluan}

Kebijakan secara etismologi diturunkan dari bahasa Yunani, yaitu "Polis" yang artinya kota (city). ${ }^{1}$ Kebijakan berarti seperangkat tujuan-tujuan, prinsipprinsip serta peraturan-peraturan yang membimbing suatu organisasi.Kebijkan (policy), menunjukan adanya serangkaian alternatif yang dipilih berdasarkan prinsip-prinsip tertentu, sedangkan kebijaksanaan (wisdon), berkenaan dengan satu keputusan yang cenderung memperbolehkan sesuatu yang sebenarnya dilarang, atau sebaliknya, karena alasan-alasan tertentu, seperti pertimbangan kemanusian, keadaan darurat yang sebenarnya. ${ }^{2}$

\footnotetext{
${ }^{1}$ Syafaruddin, Efektivitas Kebijakan Pendidikan, (Jakarta: Rineka Cipta, 2008), h. 75

${ }^{2}$ Abdul Halim Soebahar, Kebijakan Pendidikan Islam Dari Ordonansi Guru Sampai Uu Sisdiknas, (Jakarta: PT Rajagrafindo persada, 2013), h. 11
} 
Menurut Anderson dalam bukunya budi winarno ${ }^{3}$ Kebijakan ialah Pertama dalam konteks politik modern sebagai perencanaan oleh aktor-aktor yang terlibat dalam sistim politik.Kedua, kebijakan merupakan arah atau pola tindakan yang dilakukan oleh pejabat pemerintah dan bukan merupakan keputusan-keputusan tersendiri. Suatu kebijakan mencakup tidak hanya keputusan untuk menetapkan undang-undang mengenai suatu hal,tetapi juga keputusan- keputusan beserta dengan pelaksanaannya. Ketiga, mencakup bentuk tindakan pemerintah yang jelas untuk mempengaruhi permasalahan tertentu. Dalam kebijakan, juga dikenal istilah keputusan kebijakan yaitu keputusan- keputusan yang dibuat oleh pejabat- pejabat pemerintahan yang mengesahkan atau memberi arah substansi kepada tindakantindakan kebijakan publik, termasuk dalam kegiatan ini adalah menetapkan undang- undang dan peraturan-peraturan.

Sedangkan konsep kebijakan pendidikan Islam adalah konsep yang sering didengar, dikaji dan sering didiskusikan, tetapi sering kali seringkali kurang dipahami makna sesungguhnya.Karena itu, konsep kebijkan dan kebijaksanaan sering dipertukarkan antara satu dengan yang lain, baik tataran pemahaman maupun implementasinya, sehingga penjelasan singkat sangat diperluka, agar istilah kedua tersebut bisa digunakan secara tepat sesuai dengan konteksnya ${ }^{4}$.Karena dua konsep tersebut mempunyai makna yang cukup berbeda.Dari deskripsi singkat tersebut dapat dipahami bahwa kebijaksanaan sering kali dimaknai melanggar sesuatu karena alasan tertentu, sedangkan kebijakan merupakan hasil analisis yang mendalam terhadap berbagai altenatif yang bermuara pada keputusan tentang alternatif terbaik.Dengan memahami perbedaan makna kedua konsep tersebut, diharap agar masing-masing istilah tersebut digunakan degunakan secara tepat sesuai dengan konteksnya ${ }^{5}$.

\footnotetext{
${ }^{3}$ Budi winarno, Teory dan Proses Kebijakan Publik, (Yogyakarta: Med Press, 2002), h, 20

${ }^{4}$ Indah Muliati, 'Manajemen Konflik Dalam Pendidikan Menurut Perspektif Islam', Tingkap 12, no. 1 (1 April 2016): 39-52-52; Ahmad Fauzi, 'Kepemimpinan Kepala Madrasah Dalam Mengembangkan Lembaga Pendidikan Islam', Nidhomul Haq: Jurnal Manajemen Pendidikan Islam 2, no. 2 (6 December 2017): 42-53.

${ }^{5}$ Moh Khoiruddin, 'Analisis Kebijakan Kurikulum Pendidikan Islam Di Lembaga Pendidikan Islam', JOIES: Journal of Islamic Education Studies 1, no. 1 (2016): 141-154.
} 
Jadi Kebijakan pendidikan merupakan sesuatu yang sudah tidak asing lagi dalam kehidupan berbangsa, konsep yang sering kita dengar, kita ucapkan dan kita lakukan, tetapi kita tidak mengetahui maknanya.Kebijakan merupakan keputusan yang telah ditetapkan atau standing decision yang memiliki karakteristik tertentu seperti konsistensi sikap dan keberulangan bagi subyek dan obyeknya.Sementara kebijakan pendidikan dapat dimaknai sebagai kebijakan yangditetapkan oleh pemerintah untuk mengatur pendidikan di negaranya.Yang pasti, kebijakan apapun itu, selalu diwujudkan dalam bentuk keputusan yang menekankan pada implementasi tindakan, terlepas dari tindakan tersebut pada akhirnya dilakukan atau tidak. Dapat dipahami kebijakan pendidikan merupakan keseluruhan proses dan hasil perumusan langkah-langkah strategis pendidikan yang dijabarkan dari visi,misi pendidikan dalam rangka untuk mewujudkan tercapainya tujuan pendidikan dalam suatu masyarakat untuk suatu kurun waktu tertentu.

\section{Pembahasan}

\section{Peningkatan Mutu Pendidikan}

Mutu dewasa ini merupakan isu penting yang dibicarakan Hampir dalam setiap sektor kehidupan, dikalangan bisnis, pemerintah, sistem pendidikan, dan sektor lainnya. Dalam kamus besar bahasa indonesia, mutu adalah ukuran baik buruk suatu benda; kadar, taraf, derajat (kepandaian, kecerdasan dan sebagainya), kualitas. ${ }^{6}$ Dalam pengertian lain, mutu diartikan sebagai mkna drajat (tingkat) keunggulan satu produk (hasil kerja/upaya) baik berupa barang maupun jasa, baik yang tangible maupun intangible.

Sebagaimana kita ketahui bersama bahwa landasan dan dasar pendidikan islam yaitu Al-Qur'an dan Al-Sunnah belum benar-benar digunakan sebagaimana mestinya. Hal ini sebagai akibat belum adanya sarjana dan pakar diindonesia yang secara khusus mendalami pemahaman Al-Qur'an dan Al-Sunnah dalam perspektif

\footnotetext{
${ }^{6}$ Tim Penyusun Kamus Pusat Pembinaan Dan Pengembangan Bahasa, Kamus Besar Bahasa Indonesia (Jakarta: Balai Pustaka, 1996), h. 667
} 
pendidikan islam. ${ }^{7}$ Ummat islam belum banyak yang mengetahui tentang isi kandungan Al-Qur'an Al-Sunnah yang berhubungan dengan pendidikan secara baik. Akibatnya pelaksanaan pendidikan islam belum berjalan diatas landasan dan dasar ajaran islam itu sendiri.

Secara historis perkembangan pendidikan islam sangat terkait dengan kegiatan dakwah islamiyah. ${ }^{8}$ Pendidikan islam berperan sebagai mediator, dimana ajaran islaam dapat disosialisasikan kepada masyarakat dalam berbagai tingkatannya. Melalui pendidikan inilah, masyarakat indonesia dapat memahami, menghayati dan mengamalkan ajaran islam sesuai dengan ketentuan Al-Qur'an dan Asunnah. Sehubungan dengan itu tingkat kedalaman pemahaman, penghayatan dan pengalaman masyarakat terhadap ajaran islam amat tergantung pada tingkat kualitas pendidikan islam yang diterimanya.

Berdasarkan kerangka tersebut diatas, maka pendidikan islam di indonesia sering kali berhadapan dengan berbagai masalah yang tidak ringan. Salah satu permasalahan yang tidak ringan dan dihadapi oleh bangsa indonesia adalah rendahnya mutu pada setiap jenjang dan satuan pendidikan, khususnya pendidikan dasar dan menengah. Bahkan lebih naif lagi, madrasah diposisikan pada posisi yang terendah diantara lembag-lembaga pendidikan yang mempunyai kualitas rendah tersebut, yaitu sekolah negeri dan sekolah kristen. ${ }^{9}$

Rendahnya mutu pendidikan tersebut dapat diperhatikan pada hasil-hasil studi internasional yang selalu mendapatkan pendidikan indonesia dalam posisi

\footnotetext{
${ }^{7}$ Diantara buku yang membahas pendidikan islam dalam perspektif Al-Qur'an adalam muhammmad Quthb, Pendidikan Dalam Al-Qur'an dan Ali Khalil Abul Ainain, FilsafatAl Tarbiyah Al-Islamiyah Fi Al-Qur'an. Buku-buku ini ditulis dalam bahasa arab yang pada umumnya belum banyak dikenal oleh para pelajar islam di indonesia. Akibatnya pertumbuhan dan perkembangan pendidikan islam sebagai sebuah ilmu menujukkan keterlambatan dibandikan dengan studi islam lainnya seperti Fiqih, Ilmu Kalam, Tafsir, Hadis dan sebagainya. Lihat: Abudin Nata, Menejemen Pendidikan:Mengatasi Kelemahan Pendidikan Islam Di Indonesia (Jakarta: Prenada media, 2003), h. 02

${ }^{8} \mathrm{Hal}$ ini dapat dilihat dari berbagai data dan sumber sejarah masuknya islam di indonesia sebagai kegiatan dakwah islamiyah, karena secara tidak langsung masuknya islam diindonesia sekaligus mengakomodir kegiatan pendidikan islam itu sendiri. Dengan kata lain, meminjam istilah mahmud yunus, "sejarah pendidikan islam sama yuanya dengan masuknya agama tersebut ke indonesia”. Mahmud Yunus, Sejarah Pendidikan Islam Di Indonesia, (Jakarta: Hidakarya Agung, 1985), h. 6

${ }^{9}$ Muhaimin, Pengembangan Kurikulum Pendidikan Islam: di sekolah, Madrasah, dan Perguruan Tinggi(Jakarta:P.T. Radja Grafindo Persada, 2005), h. 189-190
} 
“juru kunci”. Hasil studi The Third Internasional Mathematics And Sciense Study Repeat 1999 (TIMSSS-R1999) yang dilaksanakan pada 38 negara dari lima benua, yaitu Asia, Australia, Afrika, Amrika dan Eropa menempatkan peserta didik SLTP indonesia pada urut ke 32 dan 34 untuk sekor tes IPA dan Matematika. Peserta didik dari tentanggga Singapura menduduki urutan yang pertama dan kedu untuk skor Matematika dan IPA. Indikaator lain menunjukkan bahwa berdasarkan pada Human Development Index (HDI), indonesia berada pada urut yang ke 102 dari 164 negara dan indonesia masih berada dibawah vietnam. Disamping itu hasil studi International Institute For Development menempatkan indonesia pada urutan ke 49 dari 49 negara.

Mutu dalam kontek pendidikan berkaitan dengan upaya memberikan pelayanan yang paripurna, dan memuaskan bagi para pemakai jasa pendidikan. Dalam sitem penyelenggaraan pendidikan, aspek mutu (quality) juga akan selalu berkaitan dengan bagaimana input peserta didik, proses penyelenggaraan pendidikan dengan fokus layanan peserta didik, samapai bagaimana Output lulusan yang dihasilkan.Segala menyatakan, bahwa mutu pendidikan adalah gambaran dan karakteristik yang menyeluruh jasa pelayanan pendidikan secara internal, mupun ekternal yang menunjukkan kemampuannya, memuaskan kebutuhan yang diharapkan, atau yang tersirat yang menyangkut input, proses, dan output pendidikan. ${ }^{10}$ Mutu pendidikan tidak saja ditentukan oleh sekolah sebagai lembaga pengajaran, tetapi juga disesuaikan dengan apa yang menjadi pandangan dan harapan masyarakat yang selalu berkembang seiring dengan perkembangan zaman. Bertitik tolak pada kecendrungan ini, penilaiaan masyarakat tentang mutu lulusan sekolahpun terus-menerus berkembang. Karena itu sekolah harus meningkatkan mutu lulusannya, dengan menyesuaikan perkembangan tuntutan masyarakat, menuju pada mutu pendidikan yang dilandasi tolak ukur norma yang ideal.

Maka dari itu, mutu dalam pendidikan dapat saja disebutkan mengutamakan pelajar atau program perbaikan sekolah yang mungkin dilakukan

\footnotetext{
${ }^{10}$ Syaiful Sagala, Menejemen Strategik Dalam Peningkatan Mutu Pendidikan: Pembuka Ruang Kreatifitas, Inovasi, Dan Pemberdayaan Potensi Sekolah Dalam Sistem Otonomi Sekolah (Bandung: Alfabeta 2009), h. 170
} 
secara kreatif dan konstruktif. ${ }^{11}$ Mutu dalam pendidikan memang dititiktekan pada pelajar dan proses yang ada didalamnya. Tanpa adanya proses yang baik, maka madrasah yang bermutu juga mustahil untuk dicapai. Kondisi mutu pendidikan juga dipelaporkan oleh. Suryadi dalam bukunya, Sebagai berikut: ${ }^{12}$ Kemampuan membaca (Reading Literacy) anak-anak Indonesia sangat rendah bila dibandingkan dengan negara-negara berkembang lainnya, bahkan dalam kawasan ASEAN sekali pun. International Association For Evaluation Of Educational (IEA) pada tahun 1992 dalam sebuah study kemampuan membaca murid-murid Sekolah Dasar kelas IV pada 30 negara di dunia, menyimpulkan bahwa Indonesia menempati urutan ke-29 setingkat diatas Venezuela yang menempati peringkat terakhir pada urutan ke-30. ${ }^{13}$

Data-data diatas menunjukan bahwa pendidikan di Indonesia belum bermutu. Untuk memperbaiki mutu pendidikan maka harus dipahami mengenai konsep mutu. Menurut Edward Salliss, Mutu merupakan cara yang menentukan apakah produk terakhir sesuai sesuai dengan standar atau belum. Beeby melihat mutu pendidikan dari tiga perspektif yaitu: perspektif ekonomi, sosiologi dan pendidikan. Berdasarkan perspektif ekonomi, pendidikan yang bermutu, adalah yang mempunyai kontribusi tinggi terhadap pertumbuhan ekonomi. Lulusan pendidikan secara langsung dapat memenuhi angkatan kerja di dalam berbagai

\footnotetext{
${ }^{11}$ Syafaruddin, menejemen Mutu Terpadu Dalam Pendidikan: Konsep, Strategi Dan Aplikasi (Jakarta: PT Grasindo, 2002), h. 35

${ }^{12}$ Ace Suryadi. Mewujudkan Masyarakat Pembelajar.(Bandung: Widya Aksara Press, 2009), h. 151

${ }^{13}$ Data diatas relevan dengan hasil studi dari Vincent Greannary yang dikutip oleh World Bank dalam sebuah laporan pendidikan "Education in Indonesia from Crisis to Recovery" tahun 1998. Hasil studi tersebut menunjukan bahwa rata-rata kemampuan membaca anak-anak kelas VI Sekolah Dasar di Indonesia hanya mampu meraih kedudukan paling akhir dengan nilai 51,7 setelah Filipina yang memperoleh nilai 52,6 dan Thailand dengan nilai 65,1 serta Singapura dengan nilai 74,0 dan Hongkong yang memperoleh nilai 75,5.Buruknya kemampuan membaca anak-anak kita sebagaimana data diatas berdampak pada kekurang mampuan mereka dalam penguasaan bidang ilmu pengetahuan dan Matematika. Hasil tes yang dilakukan oleh Trends in International Mathematics and Science Study (TIMSS) dalam tahun 2003 pada 50 negara di dunia terhadap para siswa kelas II SLTP, menunjukkan prestasi siswa-siswa Indonesia yang hanya mampu meraih peringkat ke-34 dengan nilai 420 dalam kemampuan bidang Matematika dengan nilai 411 dibawah nilai rata-rata Internasional 467.Hasil test bidang ilmu pengetahuan mereka harus mampu menduduki peringkat ke-36 dengan nilai 420 di bawah nilai rata-rata Internasional 474. Dibandingkan dengan anak-anak Malaysia mereka telah berhasil menduduki nilai 508 diatas nilai Internasioanl.Dan dalam bidang ilmu pengetahuan mereka menduduki peringkat ke-20 dengan nilai 510 diatas nilai rata-rata Internasional.Dengan demikian tampak jelas bahwa kecerdasan bangsa kita sangat jauh ketinggalan dibawah negara-negara berkembang lainnya.
} 
sektor ekonomi. Dengan bekerjanya mereka pertumbuhan ekonomi dapat didorong lebih tinggi. Menurut pandangan sosiologi, pendidikan bermutu adalah pendidikan yang bermanfaat terhadap seluruh masyarakat dilihat dari berbagai kebutuhan masyarakat, seperti mobilitas sosial, perkembangan budaya, pertumbuhan kesejahteraan, dan pembebasan kebodohan. Dalam konteks persekolahan, mutu dipandang sebagai kemampuan sekolah untuk merespon dan memenuhi kebutuhan murid dan masyarakat.

\section{Indikator Peningkatan Mutu Pendidikan}

Mutu pendidikan sering diindikasikan dengan kondisi yang baik, memenuhi syarat, dan segala komponen yang harus terdapat dalam pendidikan, kompononen-komponen tersebut adalah masukan, proses, keluaran, tenaga kependidikan, sarana prasarana dan biaya. Mutu pendidikan juga merupakan salah satu faktor penentu daya saing bangsa, sehingga untuk dapat tetap bisa bertahan dalam percaturan global, maka pendidikan yang bermutu mutlak diperlukan. Peningkatan mutu pendidikan merupakan sarana pembangunan di bidang pendidikan nasional, dan merupakan bagian integral dari upaya peningkatan kualitas manusia Indonesia (menyeluruh). Sebagaimana disebutkan dalam pasal 3 Undang-Undang No. 20 Tahun 2003 tentang sistem pendidikan nasional menyatakan:

"Bahwa pendidikan nasional berfungsi mengembangkan kemampuan dan membentuk watak serta peradaban bangsa yang bermartabat dalam rangka mencerdaskan kehidupan bangsa, bertujuan untuk berkembangnya potensi peserta didik agar menjadi manusia budiman dan bertaqwa kepada Tuhan Yang Maha Esa, berakhlak mulia, sehat, berilmu, cakap, kreatif, mandiri, dan menjadi warga negara demokratis serta bertanggung jawab". ${ }^{14}$

\footnotetext{
${ }^{14}$ UU RI Nomor 20 Tahun 2003 Tentang Sikdisnas (Semarang: Aneka Ilmu, 2003), h. 7
} 
Mutu pendidikan harus diupayakan untuk mencapai kemajuan yang dilandasi oleh suatu perubahan terencana menurut segala peningkatan mutu pendidikan diperoleh melalui dua strategi, yaitu: 1) peningkatan mutu pendidikan yang berorientasi akademis untuk memberi dasar minimal dalam perjalanan yang harus ditempuh untuk mencapai mutu pendidikan yang dipersyaratkan oleh tuntutan zaman, 2) peningkatan mutu pendidikan yang berorientasi pada keterampilan hidup, esensial, yang dicakupi oleh pendidikan yang berlandasan luas, nyata, dan bermakna. ${ }^{15}$

Lebih lanjut segala menyatakan, bahwa lembaga pendidikan dapat dikatakan bermutu, apabila prestasi sekolah khususnya, prestasi peserta didik, menunjukkan pencapaian yang tinggi dalam; 1) prestasi akademik, yaitu nilai raport dan nilai kelulusan memenuhi standart yang ditentukan, 2). Memiliki nilainilai kejujuran, ketaqwaan, kesopanan, dan mampu mengapresiasi nilai-nilai budaya, dan 3). Memiliki tanggung jawab yang tinggi, dan kemampuan yang diwujudkan dalam bentuk keterampilan, sesuai dengan standart ilmu yang diterimanya di sekolah. Pendidikan yang bermutu adalah pendidikan yang dapat menghasilkan peserta didik yang memiliki kemampuan, wawasan, dan keterampilan sesuai dengan standart yang ditetapkan, sehingga memiliki peluang yang cukup untuk berkompetensi di pasar kerja maupun dengan tidak mengesampingkan aspek-aspek moral dalam kehidupannya.

\section{Strategi Peningkatan Mutu Pendidikan}

Setidaknya terdapat dua faktor yang dapat menjelaskan kenapa upaya perbaikan mutu pendidikan selama ini kurang atau tidak berhasil. Pertama, strategi pembangunan selama ini lebih bersifat input oriented ${ }^{16}$. Strategi yang demikian lebih bersandar kepada asumsi bahwa bilamana semua input pendidikan telah dipenuhi, seperti penyediaan buku-buku (materi ajar) dan alat belajar

\footnotetext{
${ }^{15}$ Moh. Fathorrahman,Implementasi Menejemen Peningkatan Mutu Pendidikan Islam (Peningkatan Pendidikan Lembaga Pendidikan Islam Secara Holistik, Praktik Dan Teori) (Yogyakarta: Teras, 2012), h. 55

${ }^{16}$ Muhammad Anas Ma'arif, 'Pendidikan Islam Dan Tantangan Modernitas', Nidhomul Haq: Jurnal Manajemen Pendidikan Islam 1, no. 2 (26 March 2016): 47-58.
} 
lainnya, penyediaan sarana pendidikan, pelatihan guru dan tenaga kependidikan lainnya, maka secara otomatis lembaga pendidikan (pendidikan tinggi islam) akan dapat menghasilkan outpout (keluaran) yang bermutu sebagaimana yang diharapkan. Kedua, pengelolaan selama ini masih bersifat marco-oriented, diatur oleh jajaran birokrasi di tingkat pusat. Akibatnya banyak faktor yang diproyeksikan di tingkat makro (pusat) tidak terjadi atau tidak berjalan sebagaimana mestinya ditingkat mikro (sekolah). Dengan kata lain, bahwa kompleksitasnya cakupan permasalahan pendidikan, seringkali tidak dapat terpikirkan secara utuh dan akurat oleh birokrasi pusat. ${ }^{17}$

Abdurrahman Sholeh menyatakan bahwa ada tiga faktor yang menyebabkan mutu pendidikan mutu pendidikan menurun dan mengalami perkembangan yang tidak merata. Pertama, kebijakan penyelenggaraan pendidikan nasional yang menggunakan pendekatan educational production function atau input-output yang dilaksanakan secara tidak konsekuen. Kedua, penyelenggara pendidikan nasional dilakukan secara birokratis-sentralsistik, sehingga menempatkan sekolah madrasah sebagai penyelenggara pendidikan sangat tergantung pada keputusan birokrasi yang panjang dan kadang-kadang kebijakan yang dikeluarkan tidak sesuai dengan kondisi sekolah (Madrasah) setempat. Ketiga, peran serta masyarakat khususnya orang tua peserta didik dalam penyelenggaraan pendidikan selama ini pada umumnya lebih bersifat dukungan Input (dana), bukan pada proses pendidikan (pengambilan keputusan, monitoring, evaluasi, dan akuntabilitas). ${ }^{18}$

Visi, misi dan tujuan pendidikan tinggi pun juga masih belum berhasil dirumuskan dengan baik. Tujuan pendidikan tinggi islam seringkali diarahkan untuk menghasilkan manusia-manusia yang hanya menguasai ilmu islam ah-sih, dan visinya diarahkan untuk mewujudkan manusia yang salih dalam arti yang taat beribadah dan gemar beramal untuk tujuan akhirat. Akibat dari keadaan yang

\footnotetext{
${ }^{17}$ Umaidi, Menejemen Peningkatan Mutu Berbasis Sekolah; Sebuah Pendekatan Baru Dalam Pengelolaan Sekolah Untuk Meningkatkan Mutu Internet/Mbs/Artikel Pendidikan ( Network.Mbs.Htm. 1999), h. 11

${ }^{18}$ Abdul Rahman Shaleh, Madrasah dan Pendidikan Anak Bangsa (Jakarta: P.T.Raja Grafindo Persda, 2004), h. 243-244
} 
demikian ini, maka para lulusan pendidikan tinggi islam hanya memiliki kesempatan dan peluang yang cukup terbatas, yaitu hanya sebagai pengawal moral bangsa. ${ }^{19}$ Mereka kurang mampu bersaing dan tidak mampu merebut peluang dan kesempatan yang tersedia dalam memasuki lapangan kerja, akibatnya lulusan perguruan tinggi islam semakin termarginalisasikan dan tidak berdaya.

\section{Kendala dan Solusi Peningkatan Mutu Pendidikan}

Dalam pembukaan Undang-undang Dasar 1945 memuat cita-cita pendidikan bangsa Indonesia, yaitu mencerdaskan kehidupan bangsa. Dengan itu, harkat dan martabat seluruh warga negara akan dapat terwujud. Sekolah dan system sekolah sebagai suatu lembaga social dan pendidikan dipilih dan ditempatkan di antara system kelembagaan yang telah ada. Fungsi utama sekolah pada awalnya adalah pengajaran, setidak-tidaknya dalam terminology, namun dalam perkembangannya sekolah berfungsi majemuk dengan pendidikan sebagai intinya. Persoalan jumlah dan siapa yang perlu memperoleh pendidikan kiranya cukup jelas, yaitu semua rakyat pembentuk bangsa kita, sedangkan yang perlu dipikirkan dan di usahakan adalah kualifikasi dan mutu atau mutu, kecerdasannya, dan jalan serta cara mencapainya merupakan implikasi pesan utama cita-cita yang diletakkan oleh bapak-bapak pendiri Republik Indonesia dan pengisian pesan tersebut perlu dicari, dikaji, dan terus dikembangkan. ${ }^{20}$ Dengan melihat masalah mutu pendidikan yang rupanya sudah sangat menggelitik dunia pendidikan dewasa ini. Bukan saja bagi para professional, juga bagi masyarakat luas pun terdapat suatu gerakan yang menginginkan adanya perubahan sekarang juga dalam hal usaha peningkatan mutu atau mutu pendidikan.

Kendala peningkatan mutu pendidikan kendalapeningkatan mutu pendidikan ini, perlu di teliti dan di cermati agar kelak bangsa Indonesia dapat meningkatkan mutu pendidikan dengan lancar dan dapat bersaing di Era

\footnotetext{
${ }^{19}$ Dalam beberapa kasuistik, peran pendidikan Islam sebagai pengawal bangsapun dipertanyakan. Hal ini disebabkan adanya fenomina dimana keadaan bangsa indonesia yang mayoritas islam tidak menunjukkan ahlaknya yang makin baik. Al-hasil, keadaan menunjukkan dimana moral dan ahlak masyarakat semakin menghawatirkan. Lihat: Ibid., h. 3

${ }^{20}$ Suyata, Perbaikan Mutu Pendidikan Transformasi Sekolah Dan Implikasi Kebijakan, (IKIP Yogyakarta, 1998), h. 5-6
} 
Globalisasi.Solusipeningkatan mutu pendidikan gambaran tentang rendahnya mutu pendidikan sebelumnya telah di dahului oleh serangkaian studi yang dilakukan oleh Proyek Penilaian Nasional Pendidikan (PPNP) yang dimulai sejak tahun 1969.serangkaian studi ini telah memberikan gambaran tentang keadaan pendidikan di Indonesia pada saat itu, dan telah dijadikan landasan bagi dilaksanakan serangkaian pembaruan pendidikan yang dimulai sejak permulaan tahun 1970-an.

Dalam rangka peningkatan mutu atau mutu pendidikan, telah dilakukan berbagai kegiatan diantaranya adalah:

a. Pengembangan kurikulum termasuk cara penyajian pelajaran dan system study pada umumnya.

b. Pengadaan buku-buku pelajaran pokok untuk murid serta buku pedoman guru sekolah dasar dan sekolah-sekolah lanjutan, buku-buku pelajaran kejuruan dan tehnik untuk sekolah-sekolah yang memerlukannya dan buku-buku perpustakaan dalam berbagai bidang study pada pendidikan tinggi.

c. Pengadaan alat-alat peraga dan alat-alat pendidikan lainnya pada sekolah dasar (SD), TK, dan SLB, laboratorium IPA dan SMP\&SMA, fasilitas dan perlengkapan latihan dan praktik pada sekolah-sekolah kejuruan dan tehnik serta laboratorium untuk berbagai bidang ilmu pendidikan untuk Perguruan Tinggi.

d. Penataran guru-guru dan dosen.

e. Pengadaan buku bacaan yang sehat dan bermutu melalui perpustakaan sekolah. $^{21}$

\section{Kebijakan Peningkatan Mutu, Relevansi Lulusan PAI}

Peningkatan mutu, relevansi, dan daya saing di masa depan diharapkan dapatmemberikan dampak bagi perwujudan eksistensi manusia dan interaksinya

\footnotetext{
${ }^{21}$ Wasty.Soemanto. F. X. Soeyarno, Landasan Historis Pendidikan Islam, Usaha Nasional, (Surabaya, 1993), h.111
} 
sehingga dapathidup bersama dalam keragaman sosial dan budaya. Selain itu, upaya peningkatan mutu danrelevansi dapat meningkatkan taraf hidup masyarakat serta daya saing bangsa. Mutu pendidikan juga dilihat dari meningkatnya penghayatan dan pengamalan nilai-nilai humanisme yang meliputi keteguhan iman dan takwa serta berakhlak mulia, etika, wawasan kebangsaan, kepribadian tangguh, ekspresi estetika, dan kualitas jasmani. Peningkatan mutu dan relevansi pendidikan diukur dari pencapaian kecakapan akademik dan nonakademik yang lebih tinggi yang memungkinkan lulusan dapat proaktif terhadap perubahan masyarakat dalam berbagai bidang baik di tingkat lokal, nasional maupun global.

Kebijakan peningkatan mutu pendidikan diarahkan pada pencapaian mutu pendidikan yang semakin meningkat yang mengacu pada standar nasional pendidikan (SNP). SNP meliputi berbagai komponen yang terkait dengan mutu pendidikan mencakup standar isi, standar proses, standar kompetensi lulusan, standar pendidik dan tenaga kependidikan, standar sarana dan prasarana, standar pengelolaan, standar pembiayaan, dan standar penilaian pendidikan. Pemerintah mendorong dan membimbing satuan-satuan dan program (studi) pendidikan untuk mencapai standar yang diamanatkan oleh SNP. Standar-standar tersebut digunakan juga sebagai dasar untuk melakukan penilaian terhadap kinerja satuan dan program pendidikan, mulai dari PAUD, Dikdas, pendidikan menengah (Dikmen), PNF, sampai dengan pendidikan tinggi (Dikti). ${ }^{22}$

Peningkatan mutu pendidikan semakin diarahkan pada perluasan inovasi pembelajaran baik pada pendidikan formal maupun nonformal dalam rangka mewujudkan proses yang efisien, menyenangkan dan mencerdaskan sesuai tingkat usia, kematangan, serta tingkat perkembangan peserta didik. Pengembangan proses pembelajaran pada PAUD serta kelaskelas rendah sekolah dasar lebih memperhatikan prinsip perlindungan dan penghargaan terhadap hak-hak anak dengan lebih menekankan pada upaya pengembangan kecerdasan emosional, sosial, dan spiritual dengan prinsip bermain sambil belajar. Peningkatan mutu pendidikan pada jenjang pendidikan yang lebih tinggi semakin memperhatikan

\footnotetext{
${ }^{22}$ Renstra (Rencana Strategis) departemen pendidikan nasional (Diterbitkan Oleh Pusat Imformasi Dan Humas Departemen Pendidikan Nasional, 2007), h. 23
} 
pengembangan kecerdasan intelektual dalam rangka memacu penguasaan ilmu pengetahuan dan teknologi di samping memperkokoh kecerdasan emosional, sosial, dan spritual peserta didik ${ }^{23}$.

Upaya peningkatan mutu dan relevansi pendidikan secara berkelanjutan akan dilakukan oleh Pemerintah, pemerintah daerah, dan satuan pendidikan secara terpadu yang pengelolaannya dikoordinasikan secara terpusat. Dalam pelaksanaannya koordinasi tersebut didelegasikan kepada gubernur atau aparat vertikal yang berkedudukan di provinsi. ${ }^{24}$ Manajemen mutu tersebut akan dilaksanakan melalui kebijakan strategis sebagai berikut:

1. Mengembangkan dan menetapkan standar nasional pendidikan sesuai dengan PeraturanPemerintah Nomor 19 Tahun 2005 tentang Standar Nasional Pendidikan sebagai dasaruntuk melaksanakanpenilaian pendidikan, peningkatan kapasitas pengelolaanpendidikan, peningkatan sumberdaya pendidikan, akreditasi satuan dan programpendidikan, serta upaya penjaminan mutu pendidikan.

2. Melaksanakan evaluasi pendidikan melalui ujian sekolah oleh sekolah dan ujian nasional yang dilakukan oleh sebuah badan mandiri yaitu Badan Standar Nasional Pendidikan (BSNP). Ujian nasional mengukur ketercapaian kompetensi siswa/ peserta didik berdasarkan standar kompetensi lulusan yang ditetapkan secara nasional. Hasil ujian nasional tidak merupakan satu-satunya alat untuk menentukan kelulusan siswa pada setiap satuan pendidikan tetapi terutama sebagai sarana untuk melakukan pemetaan dan analisis mutu pendidikan yang dimulai dari tingkat satuan pendidikan, kabupaten/kota, provinsi sampai tingkat nasional.

3. Melaksanakan penjaminan mutu (quality assurance) melalui suatu proses analisis yang sistematis terhadap hasil ujian nasional dan hasil evaluasi lainnya yang dimaksudkan untuk menentukan faktor pengungkit dalam

\footnotetext{
${ }^{23}$ Nurul Indana, 'Penerapan Kurikulum Terintegrasi Dalam Mengembangkan Mutu Belajar Siswa (Studi Kasus Di Sma Darul 'Ulum 1 Unggulan Bppt Jombang)', Nidhomul Haq : Jurnal Manajemen Pendidikan Islam 3, no. 2 (17 October 2018): 121-47, https://doi.org/10.31538/ndh.v3i2.80.

${ }^{24}$ Ibid, h. 24
} 
upaya peningkatan mutu, baik antarsatuanpendidikan, antarkabupaten/kota, antarprovinsi, atau melalui pengelompokan lainnya. Analisis dilakukan oleh Pemerintah bersama pemerintah provinsi yang secara teknis dibantu oleh Lembaga Penjaminan Mutu Pendidikan (LPMP) pada masing-masing wilayah. Berdasarkan analisis itu, diberikan intervensi terhadap satuan dan program (studi) pendidikan di antaranya melalui: pendidikan dan pelatihan terutama pengembangan proses pembelajaran efektif, pemberian bantuan teknis, pengadaan dan pemanfaatan sumberdaya pendidikan, serta pemanfaatan ICT dalam pendidikan. Disamping itu untuk mempercepat tercapainya pemerataan mutu pendidikan dilakukan pemberian bantuan yang diarahkan pada satuan pendidikan yang belum mencapai standar nasional.

4. Melakukan tindakan afirmatif dengan memberikan perhatian lebih besar pada satuan pendidikan yang kualitasnya rendah, baik dilihat dari input, proses, maupun outputnya.

5. Melaksanakan akreditasi satuan dan/atau program pendidikan untuk menentukan status akreditasinya masing-masing. Penilaian dilakukan setiap lima tahun dengan mengacu pada SNP. Akreditasi juga dapat menggunakan rata-rata hasil ujian nasional dan/atau ujian sekolah sebagai dasar pertimbangan dalam penentuan status akreditasi tersebut. Hasil akreditasi dijadikan sebagai landasan untuk melakukan program pengembangan kapasitas dan peningkatan mutu setiap satuan atau program pendidikan. Pelaksanaan akreditasi ini dilakukan secara independen oleh Badan Akreditasi Nasional Perguruan Tinggi (BAN-PT), Badan Akreditasi Nasional Sekolah dan Madrasah (BAN-SM), dan Badan Akreditasi Nasional Pendidikan Nonformal (BAN-PNF). ${ }^{25}$

\footnotetext{
${ }^{25}$ Ibid, h. 25
} 


\section{Kesimpulan}

Pengawasan dan penjaminan mutu secara terprogram dengan mengacu pada SNP;untuk mewujudkan sistem pengawasan dan penjaminan mutu secara berkelanjutan.Karena itu perlu dikembangkan dan dikelola mekanisme pengawasan dan pengendalian mutu pendidikan yang mengacu pada standar nasional pendidikan. Kegiatan utamanya antara lain: pembentukan BAN-SM, BAN-PNF, BAN-PT; menyusun dan menetapkan mekanisme pengawasan dan penjaminan mutu pendidikan; menyusun dan menetapkan mekanisme pengawasan; evaluasi; dan ujian nasional untuk mengukur ketercapaian standar pendidikan yang telah ditetapkan; serta pengembangan kapasitas pengelolaan pendidikan di tingkat pusat, provinsi, kabupaten/kota, serta satuan pendidikan.Survai benchmarking mutu pendidikan terhadap standar internasional;bertujuanuntuk membandingkan kemampuan peserta didik Indonesia dengan anak di negaranegara lain dalam kemampuan/keterampilan matematika, sains, dan membaca sehingga mutu dan daya saing tingkat internasional peserta didik dapat ditingkatkan secara kompetitif.Pengembangan guru sebagai profesi;merupakan kebijakan yang strategis dalam rangka membenahi persoalan guru secara mendasar.Sebagai tenaga profesional, guru harus memiliki sertifikat profesi dari hasil uji kompetensi. Sesuai dengan usaha dan prestasinya, guru akan memperoleh imbal jasa, insentif, dan penghargaan, atau sebaliknya, disinsentif atas tidak terpenuhinya standar profesi oleh seorang guru. Pendidikan profesi guru dan sistem sertifikasi profesi pendidik akan dikembangkan baik untuk calon guru (pre service) maupun untuk guru yang sudah bekerja (in service). Standar profesi guru akan dikembangkan sebagai dasar bagi penilaian kinerja guru yang dilakukan secara berkelanjutan atas dasar kinerjanya baik pada tingkat kelas maupun satuan pendidikan.

Pembinaan dan pengembangan pendidik dan tenaga kependidikan nonformalkebijakan yang strategis dalam rangka membenahi persoalan pembinaan dan pengembangan pendidik dan tenaga kependidikan nonformal.Sebagai tenaga profesional yang harus memiliki sertifikat profesi dari hasil uji kompetensi, sesuai dengan usaha dan prestasinya untuk memperoleh 
imbal jasa, insentif, dan penghargaan, atau sebaliknya, disinsentif atas tidak terpenuhinya standar profesi.Standar profesi pendidik dan tenaga kependidikan nonformal (tutor dan tenaga lapangan pendidikan nonformal) akan dikembangkan sebagai dasar bagi pembinaan dan pengembangan serta penilaian kinerjanya, yang dilakukan secara berkelanjutan.Perluasan pendidikan kecakapan hidupmerupakan kegiatan strategis dalam peningkatan mutu dan relevansi pendidikan yang mencakup pengembangan pendidikan kecakapan hidup yang disesuaikan dengan kebutuhan peserta didik dalam rangka pengembangan kompetensi, kepribadian, kewarganegaraan, intelektual, estetika, dan kinestik pada berbagai satuan, jenis, jenjang, dan jalur pendidikan. Tujuannya agar keluaran pendidikan memiliki keterampilan untuk menghadapi tantangan kehidupan yang terus berkembang secara mandiri.

\section{Daftar Pustaka}

Syafaruddin, Efektivitas Kebijakan Pendidikan, (Jakarta: Rineka Cipta, 2008)

Abdul Halim Soebahar, Kebijakan Pendidikan Islam Dari Ordonansi Guru Sampai Uu Sisdiknas, (Jakarta: PT Rajagrafindo persada, 2013)

Budi winarno, Teory dan Proses Kebijakan Publik, (Yogyakarta: Med Press, 2002)

Tim Penyusun Kamus Pusat Pembinaan Dan Pengembangan Bahasa, Kamus Besar Bahasa Indonesia (Jakarta: Balai Pustaka, 1996)

Muhammmad Quthb, Pendidikan Dalam Al-Qur'an dan Ali Khalil Abul Ainain, FilsafatAl Tarbiyah Al-Islamiyah Fi Al-Qur'an.

Abudin Nata, Menejemen Pendidikan:Mengatasi Kelemahan Pendidikan Islam Di Indonesia (Jakarta: Prenada media, 2003).

Mahmud Yunus, Sejarah Pendidikan Islam Di Indonesia, (Jakarta: Hidakarya Agung, 1985).

Muhaimin, Pengembangan Kurikulum Pendidikan Islam: Di sekolah, madrasah, dan perguruan tinggi (Jakarta:P.T. Radja Grafindo Persada, 2005)

Syaiful Sagala, Menejemen Strategik Dalam Peningkatan Mutu Pendidikan: Pembuka Ruang Kreatifitas, Inovasi, Dan Pemberdayaan Potensi Sekolah Dalam Sistem Otonomi Sekolah (Bandung: Alfabeta 2009). 
Syafaruddin, menejemen Mutu Terpadu Dalam Pendidikan: Konsep, Strategi Dan Aplikasi (Jakarta: PT Grasindo, 2002).

Ace Suryadi. Mewujudkan Masyarakat Pembelajar.(Bandung: Widya Aksara Press, 2009)

UU RI Nomor 20 Tahun 2003 Tentang Sikdisnas (Semarang: Aneka Ilmu, 2003)

Moh. Fathorrahman,Implementasi Menejemen Peningkatan Mutu Pendidikan Islam (Peningkatan Pendidikan Lembaga Pendidikan Islam Secara Holistik, Praktik Dan Teori) (Yogyakarta: Teras, 2012).

Umaidi, Menejemen Peningkatan Mutu Berbasis Sekolah; Sebuah Pendekatan Baru Dalam Pengelolaan Sekolah Untuk Meningkatkan Mutu Internet/Mbs/Artikel Pendidikan ( Network.Mbs.Htm. 1999).

Abdul Rahman Shaleh, Madrasah dan Pendidikan Anak Bangsa (Jakarta: P.T.Raja Grafindo Persda, 2004)

Suyata, Perbaikan Mutu Pendidikan Transformasi Sekolah Dan Implikasi Kebijakan, (IKIP Yogyakarta, 1998)

Wasty.Soemanto. F. X. Soeyarno, Landasan Historis Pendidikan Islam, Usaha Nasional, (Surabaya, 1993) ${ }^{1}$

Renstra (Rencana Strategis) departemen pendidikan nasional (Diterbitkan Oleh Pusat Imformasi Dan Humas Departemen Pendidikan Nasional, 2007)

Fauzi, Ahmad. 'Kepemimpinan Kepala Madrasah Dalam Mengembangkan Lembaga Pendidikan Islam'. Nidhomul Haq: Jurnal Manajemen Pendidikan Islam 2, no. 2 (6 December 2017): 42-53.

Indana, Nurul. 'Penerapan Kurikulum Terintegrasi Dalam Mengembangkan Mutu Belajar Siswa (Studi Kasus Di Sma Darul 'Ulum 1 Unggulan Bppt Jombang)'. Nidhomul Haq : Jurnal Manajemen Pendidikan Islam 3, no. 2 (17 October 2018): 121-47. https://doi.org/10.31538/ndh.v3i2.80.

Khoiruddin, Moh. 'Analisis Kebijakan Kurikulum Pendidikan Islam Di Lembaga Pendidikan Islam'. JOIES: Journal of Islamic Education Studies 1, no. 1 (2016): 141-154.

Ma'arif, Muhammad Anas. 'Pendidikan Islam Dan Tantangan Modernitas'. Nidhomul Haq: Jurnal Manajemen Pendidikan Islam 1, no. 2 (26 March 2016): 47-58.

Muliati, Indah. 'Manajemen Konflik Dalam Pendidikan Menurut Perspektif Islam'. Tingkap 12, no. 1 (1 April 2016): 39-52-52. 